\title{
UTILIZATION PATTERN OF RESIDENTIAL TERRACE AS A TRADING PLACE IN KAMPUNG TRIDI JODIPAN MALANG
}

\author{
Adita Ronarizkia ${ }^{1}$, Yusfan Adeputera Yusran ${ }^{2 *}$ \\ ${ }^{1,2}$ Department of Architecture, Universitas Brawijaya, Malang \\ *Corresponding author; Email: yusfan@ub.ac.id
}

\begin{abstract}
Kampung Tridi, Jodipan Malang, which was initially a slum residential area has transformed now into a colorful area with a concept of colorful order, arranged linearly according to the houses pattern. This setting is positively effective to attract tourist interest to come and success in changing the aspect of social, culture and economy of the residents. The aspect which has been through adequate significant change is the economy, which is indicated from the number of residents who take benefit from their house's terrace that initially used as a conventional family area, now turn into an area of trading. This change is conducted to be economic support in order to fulfill their life needs. This research aims to identify the pattern of terrace utilization as the place where the trading activity takes place in Kampung Tridi Jodipan Malang. This research exerts the method of descriptive qualitative which identifies the pattern of terrace utilization through field survey, interview, and literature studies, while the method of analysis used behavior mapping. This research finding shows that the utilization pattern of the residential terrace as the trading spot is located exactly in the front part of the house that is the terrace. This phenomenon has occurred since this Kampung changes into a tourism spot followed to the people who see this as a chance of making money. The owner of shop houses try to separate the function but they have to compromise the issue due to the limitedness of space. Thus to accommodate that, they mix the space and making some adjustment to their houses. The houses that using the terrace as the trading spots are mostly located in the front of the main path which leads to the Jembatan Kaca (Glass-bridge) that connects Kampung Tridi with Kampung Warna-warni in the south. This indicates that the location near the main pathway is the most strategic area so that the locals are encouraged to optimize the place as an economic spot.
\end{abstract}

Keywords: Thematic Kampong; shop-house; terrace utilization.

\section{INTRODUCTION}

The trend of society's interest in tourism is currently increasing. Sector of tourism becomes an influence on the huge development of the economy as well as a supporter and stimulator of other sectors in order to improve the quality of life in a region (Wahab, 1990). The tourism site which is able to support the development of the resident's economy is a tourism site of the thematic residential area as found in Kampung Tridi, Jodipan, Malang.

In a common perspective, a slum residential area is regarded as having a negative impact on the surrounding environment. It is a good deal if the government decides to fix and reconstruct this slum area into a cleaner and better residential area. This change would improve the social, cultural, and economic condition of society (Fernanda, 2017). For instance, the reconstruction of Kampung Tridi as a tourist area located in the center of Malang city which currently reflects the success story in developing slum residential area into a tourism site through the thematic village. From the aspect of coloring selection and arrangement, this Kampung has a linear pattern which is matched to the village layout on existing conditions and each different color. Therefore, it seems to be well-ordered in the layout. The existence of this thematic village could grab the attention of the tourists who come and visit this area. This moment is then benefitted by the residents who are living in the area of Kampung Tridi to alter and take advantage of their residential area especially the terrace side to be a place of trading. It is intended to improve the income to fulfill their daily needs. In order to improve their economic level, the residents of Kampung Tridi is not only running such business-like souvenir shops and food stalls, but they also manage the parking area, entrance ticket, and public toilet for the visitors (Ningsih, 2017).

The terrace which is now utilized as the trading and transaction activity was initially occurred spontaneously, without having any plans. However, this chance was then realized by a resident to sell foods in their house's terrace, which was followed by the other residents. They utilized the concept of the shophouse where the most part of their house is used as a business place on the first floor, while the second floor is used as a living space. The concept of the shophouse or business house is initially inspired by the house of Chinese immigrant ( $\mathrm{Li}, 2018)$. The total of the business house has increased in a great number there from the snack shop to the other variety of street food. However, it also affects positively to the increase of the residents' daily income, which is bigger than the indicator of the World Bank for the daily standard of a poor family (Wulandari, 2017). 
Besides, the amount of the seller in this area definitely has similarity and difference in making business layout at their house. Thus, this research aims to identify the pattern of terrace utilization as a trading area in Kampung Tridi, Jodipan Malang.

\section{METHODOLOGY}

This research exerts method of descriptive qualitative and analysis of behavior mapping. This descriptive qualitative research aims to describe and depict the current phenomenon, in both nature and human engineering. Further, this descriptive research is executed through direct observation by examining the existing condition of the object, documentation, and interview with related informants in order to collect the relevant information with the research. The informants who are involved in this research are the sellers who are utilizing the residential terrace as a business place (Fernanda, 2017; Putri, 2018). Moreover, this research employs the method of behavior mapping in order to know the current phenomenon which is existing in the terrace that functions as a trading place (Haryadi, 2014). This method is intended to map the elements that could be the variables. Within the physical element, the condition of the existing terrace is now used as a place for trading in Kampung Tridi as well as dissemination and typology of transaction or trading place. Second, the non-physical elements like activities that occurred in surrounding, function, and role of the terrace for resident, and the tendency of its utilization. The elements would then collaborate with the previous researches and literature studies which are related to the residential terrace for life and environment, and also the utilization of terrace to improve the economic condition.

The process of data collection and observation is executed in the research location, while the research sample is then selected into eight residential areas. This selection is based on the criteria of the residential area that functions its terrace as a trading place in Kampung Tridi, Jodipan Malang.

\section{RESULTS and DISCUSSION}

\section{Utilization of Terrace as an Economic Supporter}

A house basically functions as a living space as well as a family gathering place. As time passes, the need of each individual is certainly different, where the house is claimed to comply with the activities of the individual who lives inside. This development would affect the process of functional change in the house. For instance, a particular space within a house might alter to be a business activity place which aims to support the economic need of residents.
According to Rapoport (1969), the change of physical setting elements of the house in the form of material is divided into three types, they are:

1. Fixed element means an element which is basically constant and has rare change.

2. Semi-fixed element means an element which is basically rather constant elements and has faster and easier change.

3. Non-fixed element means an element which is not related to the fluctuating human behavior.

The alteration of the trading area certainly needs to think about and consider the certain standards to fulfill the aspect of comfort, although it has been under alteration or functional addition of space, since the part of the house which functions as living space has a more private characteristic than the other part which functions as trading space (Amelia, 2015). Based on Silas (2000) due to the function, a living house has two categories: a basic house that is particularly used as living space and a productive house that is partly used as business function or economic activities. This kind of house is then divided into three types mentioned below:

1. Type of mixture

The type of mixture refers to a type of living house which functions as a working space. However, within this type of house, the function of living house is still more dominant than the function of work.

2. Type of equilibrate

The type of equilibrate refers to a type of living house which occupies distinct separation between the function of living house and working even within a single and similar area. Access to the working space might be affirmed and separated.

3. Type of separation

The type of separation refers to a type of living house which the function of working space is more dominant than the function of living. Occasionally, the living space is only occupied on the back of the working space or instead is merged into the working space.

Based on the types of residential business house, it is concluded that the residential business house or home-based business is a form of space utilization in a house, which is seen from several factors like having limited space for business and working place or although with no any distinct separation. Besides, based on the previous research that has been conducted by Taufikurrahman (2010) related to the change of space layout as an effect from the activity of home industry (craftsman of metal industry) in Desa Ngingas, Sidoarjo was found four types of house or productive house from the aspect of space utilization layout to be the living house function rather than the business one, that is: 
1. Type of house where the business space is in outdoor space is separated from the house, even in one territory of the house.

2. Type of house where the business space is indoor (specific room) by having elements of distinct separation territory.

3. Type of house where the business space is merged into the living house.

4. Type of house where the business space is beside, behind, or in front, within a house building.

Those types of house are employed in this research in order to identify the layout of business space to the living space. It aims to clarify the pattern of utilization from each function of the residential business house.

\section{Factors in Determining The Residential Space Layout for Business}

According to Rapoport (1969), he stated that the layout of house utilization in the architectural aspect is affected by a number of factors, like primary factor which is related to social-culture factor, and modifying factor which is consisted of factor of climate, factor of material, factor of construction, factor of technology, and factor of land or site. Most of the factor that is able to affect the layout formation of space utilization is the limited space and the economy factor. Then, the resident tends to choose to change the proper function of a house as a living facility into a business function in order to support the economic needs of the family.

The location of research is in Kampung Tridi, Jodipan particularly at Temanggungan Ledok Street, Kesatrian, Blimbing, Malang, East Java. This research focus is on the residential area which functions the terrace as a place of trading or business. Moreover, the researcher selects eight residential areas to be the research object. This number of the object is based on the result of observation and purposive sampling implementation which highlights on the criteria of terrace function as a trading place.

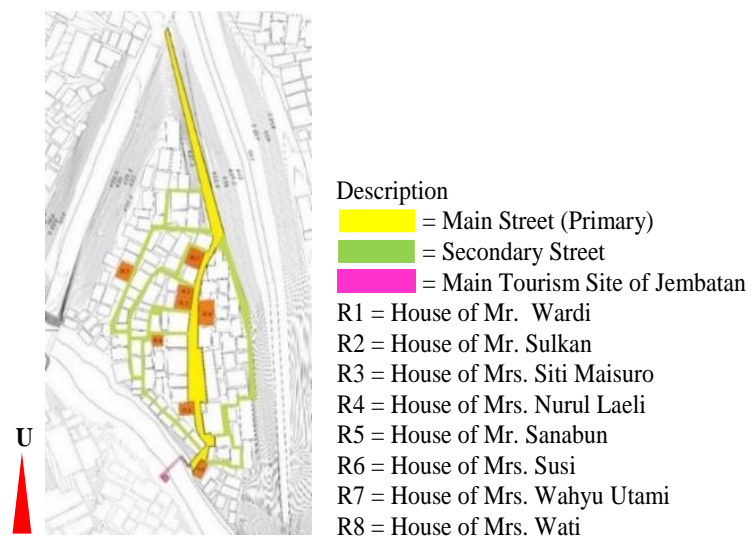

Fig. 1. Jodipan Multicultural Settlement Patterns

\section{Space Orientation}

The orientations of the houses which function the terrace as trading place are commonly heading to the street. It aims to attract the visitor's interest to buy or eat in each place of their little shop. Moreover, a few residential houses seem like enforcing their front space of the house to be a trading area. Initially, from the aspect of location, their houses are not supposed to be the trading or business area because of some effects of thematic village development and construction in that area. However, to improve the income of the family, many residents enforce their selves to take benefit from their little yard or terrace, even when it is close and directly in front of to the street corridor.

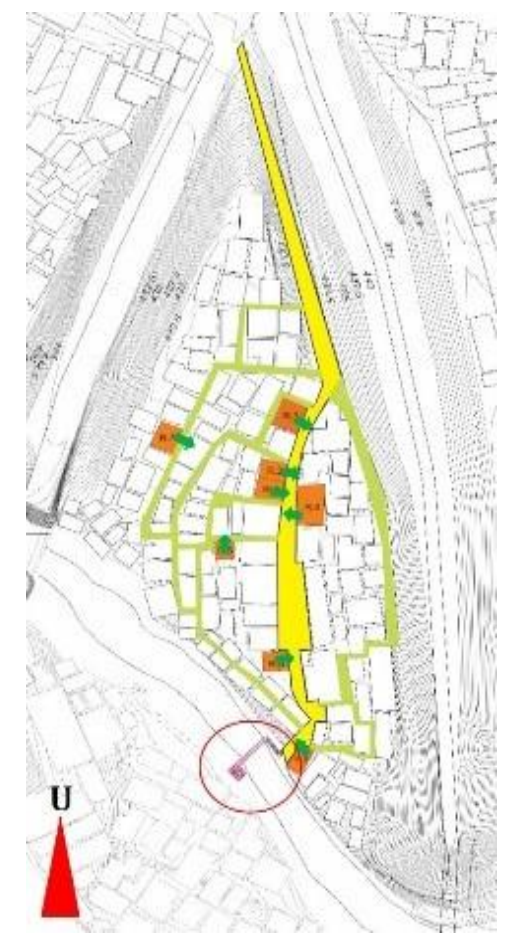

Fig. 2. Building Orientation

\section{Space Utilization Pattern}

Residents of KampungTridi tend to execute collective activity since they have a variety of facilities and functions. The most utilization is exerted on the street heading to Jembatan Kaca (Glass Bridge) as a connecting bridge between the two thematic villages of the colorful concept that is Kampung Tridi and Kampung Warna Warni which is located in the south side of the KampungTridi. The residential terrace is an adaptable space where the sellers transform the transaction place by implementing semi-fixed elements. This element means that the alteration of residential terrace with its initial function tends to be unchanged and not prominent. 
Tabel 1. Description of the houses which apply the terrace as a trading or business place

\begin{tabular}{|c|c|c|c|}
\hline $\begin{array}{l}\text { House } \\
\text { Owner }\end{array}$ & $\begin{array}{l}\text { House Plan which Functions the } \\
\text { Terrace as a Trading Place }\end{array}$ & $\begin{array}{l}\text { Condition of Terrace } \\
\text { as a Trading Place }\end{array}$ & Description \\
\hline $\begin{array}{c}\text { Mr. } \\
\text { Wardi }\end{array}$ & $=\underset{\mathbf{U}}{\mid}$ & anter & $\begin{array}{l}\text { Having two floors, where the } \\
\text { grocery store is in front of the } \\
\text { house, then it is altered to } \\
\text { function the terrace as a food } \\
\text { stall or noodle shop to increase } \\
\text { the need for the economy } \\
\text { - Type of Product: Snack and } \\
\text { Noodle Shop } \\
\text { - Type of House: Mixture } \\
\text { function where the space of } \\
\text { working and living are } \\
\text { merged }\end{array}$ \\
\hline $\begin{array}{c}\text { Mr. } \\
\text { Sulkan }\end{array}$ & Plan 1st Floor & & $\begin{array}{l}\text { Having only one floor, where } \\
\text { the terrace in front of the house } \\
\text { is separated as a space of shop } \\
\text { and food stall which is located } \\
\text { directly in front of the house } \\
\text { entrance door. It might cause to } \\
\text { the problem of circulation } \\
\text { nuisance. } \\
\text { - Type of Product: Snacks and } \\
\text { Warung Rujak Cingur } \\
\text { - Type of House: Mixture } \\
\text { function where the space of } \\
\text { living and working is merged }\end{array}$ \\
\hline $\begin{array}{l}\text { Mrs. Siti } \\
\text { Maisuro }\end{array}$ & Plan 1st Floor & & $\begin{array}{l}\text { Having two floors where the } \\
\text { first floor is mostly utilized as a } \\
\text { function of business space } \\
\text { including to a public zone, } \\
\text { while the second floor is } \\
\text { entirely utilized as private zones } \\
\text { like the area of bedroom and } \\
\text { family room. } \\
\text { Type of Product: Packaging } \\
\text { beverage } \\
\text { Type of House: Mixture } \\
\text { function where the living and } \\
\text { working space is merged }\end{array}$ \\
\hline $\begin{array}{c}\text { Mrs. } \\
\text { Nurul } \\
\text { Laeli }\end{array}$ & Plan 1st Floor & $=7 \times 15$ & $\begin{array}{l}\text { Having two floors where most } \\
\text { of the space on the first floor is } \\
\text { utilized as a business place for a } \\
\text { salon, play station, and food } \\
\text { stall. } \\
\text { - Type of Product: Fried snack } \\
\text { and side dish } \\
\text { - Type of House: Mixture } \\
\text { function where the living and } \\
\text { working space is merged }\end{array}$ \\
\hline
\end{tabular}




\begin{tabular}{|c|c|c|c|}
\hline $\begin{array}{l}\text { House } \\
\text { Owner }\end{array}$ & $\begin{array}{l}\text { House Plan which Functions the } \\
\text { Terrace as a Trading Place }\end{array}$ & $\begin{array}{l}\text { Condition of Terrace } \\
\text { as a Trading Place }\end{array}$ & Description \\
\hline $\begin{array}{c}\text { Mr. } \\
\text { Sanabun }\end{array}$ & 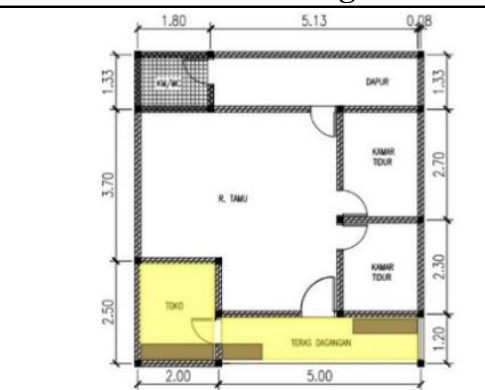 & & $\begin{array}{l}\text { Having only one floor and } \\
\text { grocery shop and food stall in } \\
\text { front of the house. } \\
\text { - Type of Product: Stand of } \\
\text { snacks, packaging beverage, } \\
\text { and ice cream } \\
\text { - Type of House: Mixture } \\
\text { function where the living and } \\
\text { working space is merged }\end{array}$ \\
\hline Mrs. Susi & $\underbrace{}_{\mathbf{U}}$ & 4 & $\begin{array}{l}\text { Having only one floor and a } \\
\text { little wide terrace space to cook } \\
\text { and sell side dishes or other } \\
\text { kinds of food including to the } \\
\text { place for the buyers. } \\
\text { - Type of Product: Warung } \\
\text { Makan Lauk Pauk and snacks } \\
\text { - Type of House: Mixture } \\
\text { function where the living and } \\
\text { working space is merged }\end{array}$ \\
\hline $\begin{array}{l}\text { Mrs. } \\
\text { Wahyu } \\
\text { Utami }\end{array}$ & Plan 1st Floor & ${ }^{3}$ & $\begin{array}{l}\text { This house was initially has a } \\
\text { grocery shop. And, now, it } \\
\text { develops to the beverage and ice } \\
\text { cream shop which is located in } \\
\text { front of house, since it has a } \\
\text { limited space. } \\
\text { - Type of Product: Grocery and } \\
\text { ice cream shop } \\
\text { - Type of House: Mixture } \\
\text { function where the living and } \\
\text { working space is merged }\end{array}$ \\
\hline $\begin{array}{l}\text { Mrs. } \\
\text { Wati }\end{array}$ & 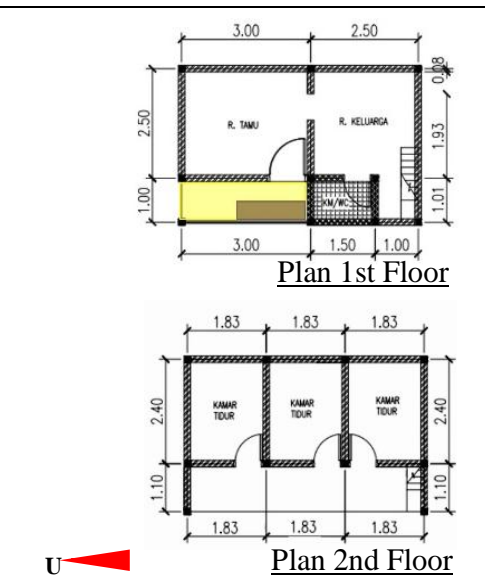 & 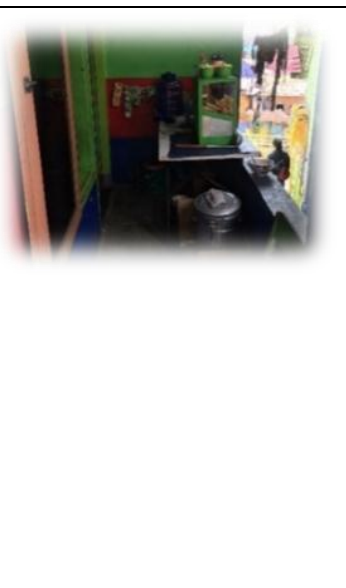 & $\begin{array}{l}\text { Having two floors where the } \\
\text { second floor is utilized as a } \\
\text { private area, while the first floor } \\
\text { as a public and semi-public } \\
\text { area. } \\
\text { - Type of Product: Warung } \\
\text { Bakso } \\
\text { - Type of House: Mixture } \\
\text { function where the living and } \\
\text { working space is merged }\end{array}$ \\
\hline
\end{tabular}


There is only a little alteration to change the function of the residential terrace to be the function of trading, especially to the business of culinary which has a purpose to support and facilitate the function of tourism site in KampungTridi. The space layout on the residential house is certainly distinguished from the space of trading function. Therefore, it arouses a variety of terrace utilization pattern from each residential trading house, as they are mentioned below:

1. Type of house where the function of the business is in the outdoor space, yet it is still in a single house territory.

This type of residential place is included in the type of pattern 1 , where the function of business is located in the outside of the house, yet within the territory of the resident's house. It is seen on R4 and R6. The two houses belong to Mrs. NurLaeli and Mrs. Susi. They locate and utilize the business space in the yard, which is not counted as a part of the house, yet it is located within a single territory of each house.
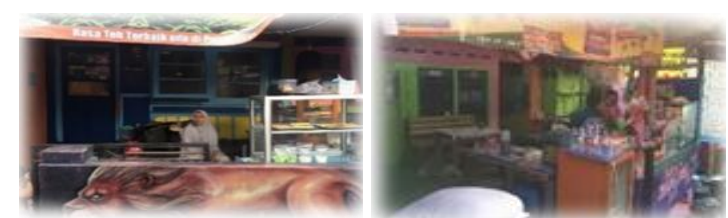

The house of Mrs Nur Laeli The house of Mrs. Susi (R6) (R4) The business space is The business space is located in located in a large front yard next to the area of motorcycle

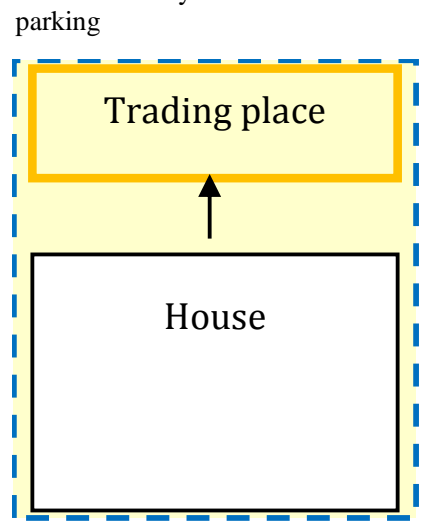

Fig. 3. Diagram of Layout of Pattern Type 1

2. Type of house where the function of business is beside, behind or even front of the house, yet they are still in a single house building.

This type of residential place is included in the type of pattern 4, where the function of business is located in front of the house; even it is still in a similar house building. The houses which function the terrace in front the house in the same building are the house of $\mathrm{Mr}$. Wardi (R1), the house of Mr. Sulkan (R2), the house of Mrs. SitiMaisuro (R3), the house of Mr. Sanabun (R5), the house of Mrs. WahyuUtami (R7), and the house of Mrs. Wati (R8).

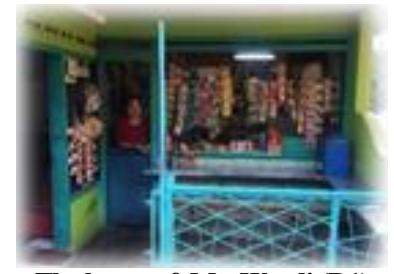

The house of Mr. Wardi (R1)

The business pace is located in front of house, while the grocery shop and noodle stall is located in terrace

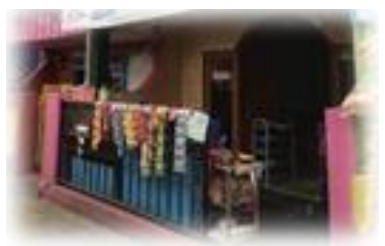
(R3)

The business space is in front of house by utilizing whole space of terrace as a place of beverage stall

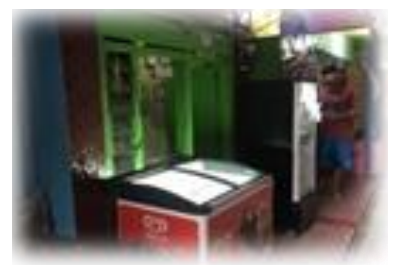

The house of Mrs. Wahyu Utami (R7) The business space located in while the ice cream stall is in terrace space.
The house of Mrs. Siti Maisuro front of house is grocery shop,

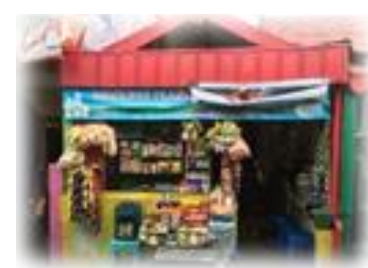

The house of Mr.Sulkan (R2)

The business space is in front of house and whole terrace space used as a shop and Warung Rujak

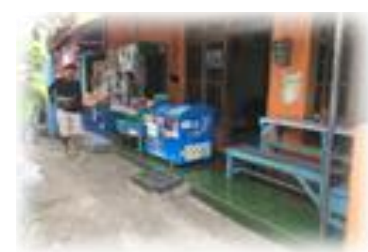

The house of Mr. Sanabun (R5) The business space located in front of house is a shop, while the food stall is in the terrace space

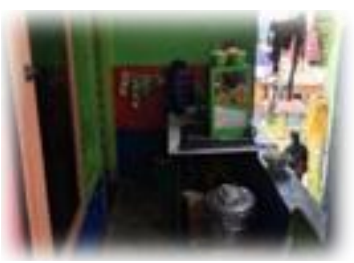
The business space is located in front of house and whole space of terrace as a place of bakso stall. It causes to the unstable circulation
The house of Mrs. Wati (R8)

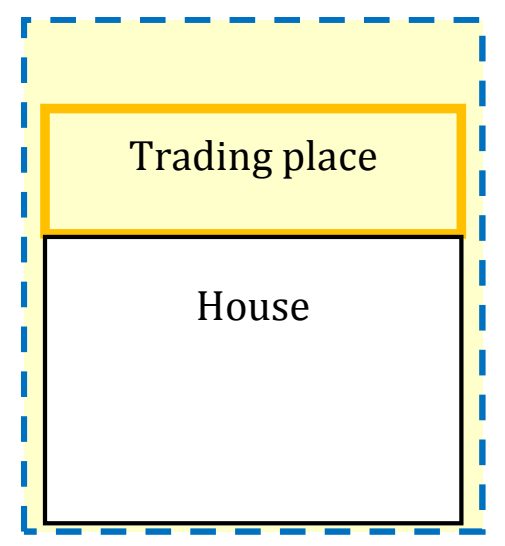

Fig. 4. Diagram of Layout of Pattern Type 4

\section{Factor of Space Layout Formation}

The level of completeness of a variety of product depicts the level of economic and social among the seller in KampungTridi. The higher level of product variety completeness could determine the economic and social level of the seller. Based on the analysis result, it indicates two layout patterns of terrace utilization which is used as the business space. Those patterns are influenced by: 
1. Economy factor

The house type of Mrs. NurLaeli (R4) and Mrs. Susi (R6) is a separated house between the business space and living space. Initially, this house was only utilized as a terrace or yard. After KampungTridi is changed to a tourism site and the level of the economy is improved, this house, then added some spaces to benefit the existing space outside the house. It refers to the terrace utilization as the trading or business space because of the limited space of the house.

2. Social factor

This type of house has trading or business spaces in the outdoor area and separated from the main house. It indicates that the owner intends on the distinct separation between the business space and the main living space. Moreover, it also shows Javanese etiquette and culture identity of Javanese.

\section{CONCLUSION}

Based on the analysis, as found in all of the case studies, the physical setting of each house has various setting but dominantly occur as non-fixed. It can be identified since this Kampung transforms into a tourism spot followed to the people who see this as a chance of making money. The owner of shop-houses try to separate the function but they have to compromise the limitedness issue of space. Eventually, they mix the space to accommodate the function both for living and selling but separated by a combined fixed element with the semi-fixed element, usually by brick walls with a big opening.

Meanwhile, reflecting on Taufikurrahman's research, it indicates that the utilization pattern of terrace space where the culinary transaction takes place is mostly exerting the fourth pattern, which the pattern of living or residential space and business space placed in the front of the house. This state happens due to the majority of resident utilize the narrow residential area of Kampung Tridi with dense population. Thus, it is difficult to add a new building or even makes a separation to create a new place as a business spot. The resident finally optimizes their terrace as a business spot since most of the houses are facing the main street or alley. Consequently, this area becomes the most crowded and the highest visited spot. The chance of business in this kampung has improved the quality of economic and social of the residents. But, the space utilization should be adjusted to the kind or variety of the sale product, in order to avoid the product excess which can intrude the circulation of each residential house.

\section{REFERENCES}

Amelia, R., Antariksa, and Suryasari, N. (2015). Tata Letak Ruang Hunian-Usaha Pada Rumah Lama Milik Pengusaha Batik Kalangbret Tulungagung. Jurnal Mahasiswa Arsitektur Universitas Brawijaya. 3(2): 1-10.

Fernanda, F., A. L. Kusuma, and U. K. Petra (2017). Kreativitas Masyarakat Kota Malang Dalam Membentuk Identitas Kota. Prosiding Seminar Nasional Seni dan Desain: "Membangun Tradisi Inovasi Melalui Riset Berbasis Praktik Seni \& Desain" FBS Unesa. 189-195.

Haryadi; Setiawan. B. (2014). Arsitektur Lingkungan dan Perilaku:Pengantar ke Teori Metodologi dan Aplikasi. Kedua, Agu. Gajah Mada University Press.

Li, S. (2018). Ecological Design of Lighting and Ventilation in Traditional Shophouses in Urban Southeast Asia. Welsh School of Architecture Cardiff University.

Ningsih, T.R. (2017) Kampung Wisata Warna Warni Jodipan Kota Malang, Berkelanjutan Atau Sementara?. Prosiding Scan\#8: Education. Putting Eco-Dna In Our Kids" Universitas Atma Jaya Yogyakarta. 155-166.

Putri, T. N., Sidi, B.D., Rahmi M., and Samsirina (2018). Building Facade Transformation of Shophouses Viewed From Sustainability Principles Case Study: Shophouses in Bandung City. HABITechno 3 International Conference. IOP Conference Series: Earth and Environmental Science. 152: 1-10.

Rapoport, A. (1969). House form and Culture (Foundations of Cultural Geography Series). Englewood Cliffs, N.J.: Prentice Hall.

Silas, J. (2000). Rumah Produktif Pendekatan Tradisi dan Masyarakat. Laboratorium Perumahan dan Permukiman Jurusan FTSP ITS; UPT Penerbitan ITS, Edisi Pertama, Surabaya.

Taufikurrahman (2010). Perubahan Pola Tatanan Ruang Rumah Tinggal sebagai Akibat Kegiatan Industri Rumah Tangga (Studi Kasus Pengrajin Logam di Desa Ngingas Kecamatan Waru Kabupaten Sidoarjo). Prosiding Seminar Nasional Perumahan Permukiman dalam Pembangunan Kota 2010. Jurusan Arsitektur ITS. 115.

Wahab, S. A. (1990) Analisis Kebijaksanaan dari Formulasi Ke Implementasi Kebijaksanaan Negara. Jakarta; Bumi Aksara.

Wulandari, P. K. (2017). Inovasi Pemuda Dalam Mendukung Ketahanan Ekonomi Keluarga (Studi Di Kampung Warna-Warni Kelurahan Jodipan, Kecamatan Blimbing, Kota Malang). Jurnal Ketahanan Nasiona,. 23(3): 300-319. 